\title{
DRYING OF BANANA SLICES UNDER VACUUM-INFRARED HEATING SYSTEM
}

\section{R. M. Kamel ${ }^{1}$ ，M. M. El-kholy ${ }^{2}$ and I. A. Abdelmotaleb ${ }^{3}$}

\begin{abstract}
\end{abstract}
A combined vacuum-infrared (IR) drying system was tested for drying bananas slices as heat-sensitive material. Thirty two experimental runs were performed at the following conditions: drying vacuum of 0.2, 0.4, 0.6 and 0.8 bar; controlled temperatures at banana surfaces of 60, 70, 80 and $90^{\circ} \mathrm{C}$; thickness of banana slices of $1 \mathrm{~mm}$ and $5 \mathrm{~mm}$. Three different thin layer drying models (Lewis's; Henderson and Pabis's; Logarithmic model) were examined to assess the most proper drying model for simulating and describing the drying behavior of banana slices under the studied experimental parameters. Physical quality of banana slices was evaluated in terms of color, rehydration ratio, shrinkage, crispness and hardness. The results showed that the changes of slices surface temperature have more significant effect on drying time than changes of drying vacuum and slices thickness. The Logarithmic model is recommended for describing the drying behavior and predicting the change of moisture ratio of banana slices in comparison with the other studied drying models. The combined vacuum -infrared drying method at drying vacuum of 0.8 bar, slices surface temperature of $80{ }^{\circ} \mathrm{C}$ and slices thickness of $1 \mathrm{~mm}$ are considered the most proper drying parameters for banana slices under the studied drying system.

\section{INTRODUCTION}

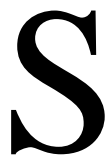
nack foods such as potato chips, onion rings, banana chips and apple chips are normally fried with vegetable oil, which provides crispness after processing. However, fried products raise major concerns by conscious consumers due to its oil content. To avoid this situation, drying process can effectively be utilized. There are many drying techniques available to dry products, but the most common technique is hot air drying.

\footnotetext{
${ }^{1}$ Assistant Researcher, Agric. Eng. Res. Inst., Dokki, Giza.

${ }^{2}$ Head Research and Deputy Director, Agric. Eng. Res. Inst., Dokki, Giza.

${ }^{3}$ Professor, Agric. Eng., Dept., Faculty of Agric., Kafrelsheikh University.
} 
However, hot air drying yields a non-crisp product because its moisture content cannot be reduced to the desired value for crispiness. Therefore, this process may not be an appropriate technique for producing a snack for which the crisp texture is preferred (Thuwapanichayanan et al., 2012). Banana is an important fruit crop in Africa and in Egypt, due its great economic importance, as well as nutritional value and high availability throughout the year. In Egypt, the average cultivated area of banana decreased from 37,925 Fed. in 2013 to 29,956 Fed. in 2014 with a decrease of $21.01 \%$ of the cultivated area. However, the production increased from 522,089 ton in 2013 to 607,688 ton in 2014 with an increase of $16.39 \%$ (MoA, 2014). Vacuum drying is a process in which products are dried in a reduced pressure environment which lowers the heat required for rapid drying. The lower pressure allow drying temperature to be reduced and higher quality to be obtained compared to the traditional methods, such as crispness, puffed structure, preservation of natural color, shape, aroma and flavor of fresh fruits, as well as loss minimization of vitamins and minerals (Jaya and Das, 2003). Moreover, some researchers found that infrared drying is able to give better qualities of product such as color, shrinkage, hardness, crispness, ascorbic acid, and total phenol contents (Nimmol et al., 2007; Timoumi et al., 2007; Boudhrioua et al., 2009; Wanyo et al., 2011).To combine the benefits of the above drying techniques, a combination of vacuum and infrared (IR) is proposed and tested with Egyptian bananas (variety Williams) which is used as a model heat-sensitive material to investigate the effects of the combined system on the product quality and processing characteristics. The outcome would provide an innovative approach to further research and development. The specific objectives of this study are to: 1) Determine the drying characteristics and quality changes of banana slices during drying using a combined vacuum-infrared drying system. 2) Investigate the effects of various operating parameters, i.e., slices surface temperature, drying vacuum and thickness of slices on the drying kinetics and simulating the drying behavior of banana slices using different thin layer drying models. 3) Assess the quality and nutrition value of the dried bananas in terms of (color, shrinkage, rehydration behavior and texture change).

\footnotetext{
${ }^{1}$ An Egyptian unit of agriculture area, one faddan $=4200.83 \mathrm{~m}^{2}$.
} 


\section{MATERIALS AND METHODS}

\subsection{Preparation of raw materials:}

Fresh bananas (variety Williams) were purchased from a local market in Kafrelsheikh, Egypt. A ripeness level of green tip (color index no. 5) was used. The fresh bananas were in initial moisture content at the range of 234.4-270.6\% (d.b.). The bananas were peeled and sliced using a special blade to get slices thickness of 1 and $5 \mathrm{~mm}$.

\subsection{The experimental scale vacuum-infrared dryer:}

A schematic diagram of the vacuum-infrared dryer is shown in Figure 1. The experimental setup consisted of a vacuum dryer (pressure pot), a silica gel filter, air tank 22 liters and oil vacuum pump (Dual stage vacuum pump model VE245N). A vacuum gauge for monitoring the vacuum pressure charge; and a vacuum regulator for precise adjustment of the pressure level were installed. The vacuum gauge is made of stainless steel and filled with glycerin oil to enhance the reliability and integrity readings and helps dampen the effect of vibration and pulsation. The vacuum regulator provided a uniform vacuum regulation independent of vacuum supply changes and full demand.

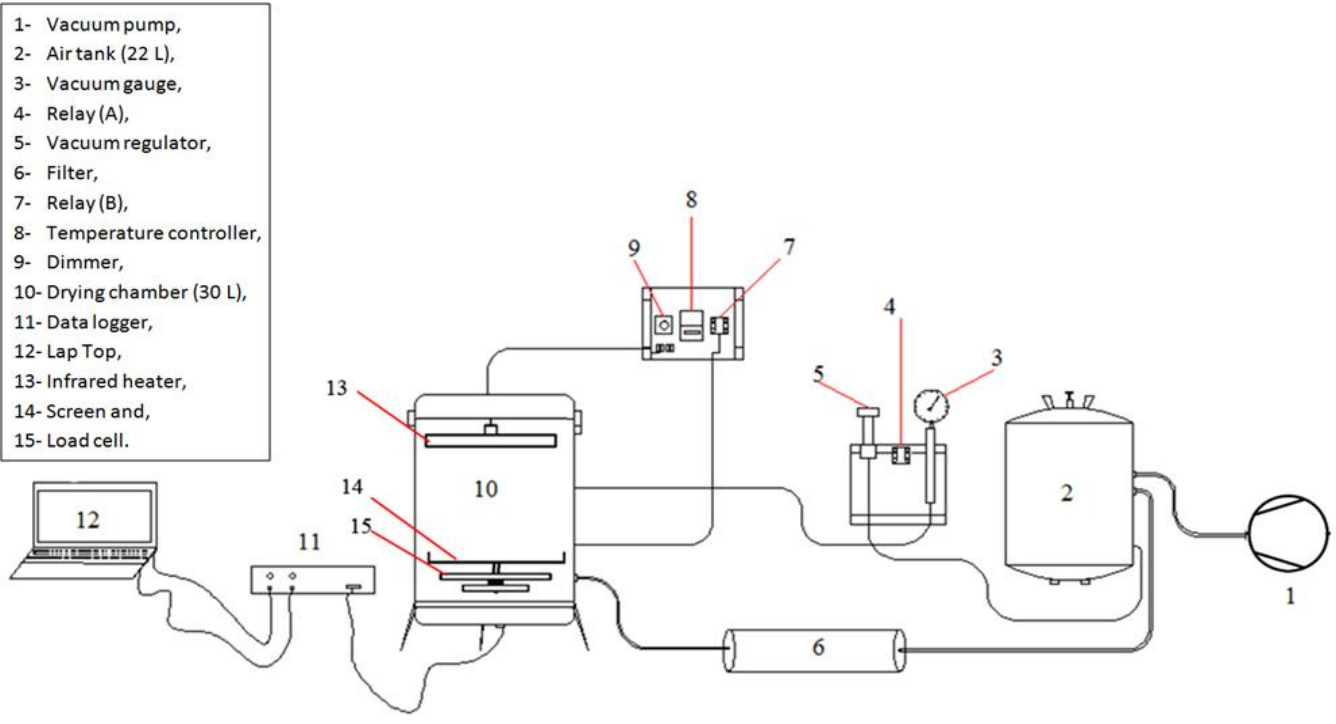

Figure (1): A schematic diagram of the vacuum-infrared dryer.

The drying chamber was constructed from an aluminum pressure pot, insulated carefully with rock wool. The chamber has diameter of $312 \mathrm{~mm}$, 
a height of $320 \mathrm{~mm}$, and a wall thickness of $6 \mathrm{~mm}$. The aluminum lid of the drying chamber has the same thickness of $6 \mathrm{~mm}$. The banana slices were dried by placing them in the vacuum drying chamber, and then simultaneously starting the infrared heating process while reducing the pressure. A far-infrared radiator (Elstein FSR ceramic panel radiator) was installed at the top of the drying chamber, to supply thermal radiation directly to the drying samples. The power of FIR heater was regulated at $250 \pm 2 \mathrm{~W}$, and emits thermal radiation in a wavelength range of $2-10 \mu \mathrm{m}$. The distance between the FIR heater and the drying tray was $15 \mathrm{~cm}$. The sample was placed on the drying tray ( $23 \mathrm{~cm}$ diameter). A filter contains silica gel and $\mathrm{CaCl}$ was installed to the drying circuit for absorbing the water vapor exit from the banana slices to present it from mixing with the oil of the vacuum pump.

\subsection{Test procedure and measurements:}

The operation of the far-infrared radiator was controlled through a temperature controller model (Omiron Model ESC4). The temperature of banana slices during the drying process was measured above the sample surface via a thermocouple type $\mathrm{J}$ with an accuracy of $\pm 1^{\circ} \mathrm{C}$. To control the surface temperature of bananas a temperature controller was used for switching on/off the heater. The tip of the thermocouple was inserted above banana slices from that side which was not exposed directly to infrared radiation. The change of samples mass during the drying process was detected continuously (at $1 \mathrm{sec}$ interval) using a load cell (OMEGA's LC601) with an accuracy of $\pm 0.01 \mathrm{~g}$. The load cell was connected to an Arduino with a HX711 amplifier / 24 bit analog- to-digital converter (ADC). For drying tests, $100 \mathrm{~g}$ of $5 \mathrm{~mm}$ banana slices thickness and $50 \mathrm{~g}$ of $1 \mathrm{~mm}$ banana slices thickness, were evenly spread at one layer on the middle section of the tray and heated from the top portion. A vacuum pump was preheated until the selected drying temperate was reached then switched on to evacuate the drying chamber to the desired operating vacuum pressure. Thirty two experimental runs were performed at the following conditions: drying vacuum of $0.2,0.4,0.6$ and 0.8 bar; controlled temperatures at banana surfaces of $60,70,80$ and $90{ }^{\circ} \mathrm{C}$; thickness of banana slices of $1 \mathrm{~mm}$ and $5 \mathrm{~mm}$; power of FIR heater was regulated at $250 \pm 2 \mathrm{~W}$. The drying experiments were performed until 
the final moisture content of bananas was less than 5\% (d.b.), or when the dried slices become crispy.

\subsection{Modeling of the Drying Process:}

The moisture ratio $(M R)$ of each sample during the drying process and the drying rate of the samples were determined by the following equations:

$$
M R=\frac{M-M_{e}}{M_{o}-M_{e}}
$$

(Zakipour and Hamidi, 2011)

Where:

$M R=$ moisture ratio

$M=$ moisture content at time $t$

$M_{o}=$ initial moisture content;

$M_{e}=$ equilibrium moisture content.

The equilibrium moisture content $\left(M_{e}\right)$ was assumed to be zero for this experiment because it is very small as compared to $\left(M_{o}\right)$. In this study three drying models were examined to check their applicability in describing the drying behavior of banana slices, as shown in Table 1 .

Table (1): The examined mathematical models used for describing the drying data.

\begin{tabular}{lcl}
\hline Model name & Model equation & References \\
\hline Lewis's & $M R=\exp (-k t)$ & Lewis $(1921)$ \\
Henderson and & $M R=\mathrm{A} \exp (-k t)$ & $\begin{array}{l}\text { Henderson and Pabis } \\
\text { Pabis's }\end{array}$ \\
Logarithmic & $M R=\mathrm{B} \exp (-k t)+C$ & Yagcioglu et al. (1999) \\
\hline
\end{tabular}

Where: $\mathrm{t}=$ drying time; $k, \mathrm{~A}, \mathrm{~B}$ and $\mathrm{C}=$ drying constants.

To select the best model for describing the drying curves the selected thin layer drying equations were tested. The coefficients of each model were calculated using STATISTICA software. The goodness of fit was evaluated by the coefficient of determination $\left(R^{2}\right)$, mean bias error $(M B E)$, the root mean square error (RMSE) and the mean square of the deviations between the experimental and calculated values or chi square $\left(x^{2}\right)$ defined by Equations (2) through (4). The best model describing the drying process of banana slices was chosen as the one with the highest $R^{2}$ and the least RMSE and $x^{2}$ (Zakipour and Hamidi, 2011). 


$$
\begin{aligned}
& x^{2}=\frac{\sum_{i=1}^{N}\left(M R_{\text {calc. }, i}-M R_{o b s ., i}\right)^{2}}{N-n} \\
& M B E=\frac{1}{N} \sum_{i=1}^{N}\left(M R_{\text {calc. }, i}-M R_{o b s ., i}\right) \\
& R M S E=\left[\frac{1}{N} \sum_{i=1}^{N}\left(M R_{\text {calc. }, i}-M R_{o b s ., i}\right)^{2}\right]^{1 / 2}
\end{aligned}
$$

(Sarsavadia et al., 1999; Pangavhane et al., 2000)

Where $M R_{o b s ., i}$ stand for the observed moisture ratio found in any measurement and $M R_{\text {calc., } i}$ is the calculated moisture ratio for this measurement. $N$ and $n$ are the number of observations and constants, respectively.

\subsection{Quality Evaluation of Dried Banana Slices:}

The physical qualities of banana slices were evaluated for color, rehydration ratio, shrinkage and texture in terms of crispness and hardness.

\subsubsection{Shrinkage measurement:}

The shape of samples in this study is shown in Figure 2. The shrinkage of the dried sample was calculated by the following equation:

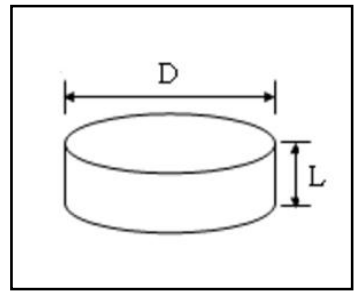

Figure (2): The dimensions of dried banana slices.

$\%$ Thickness shrinkage $=\left(\frac{\mathrm{L}_{0}-\mathrm{L}}{\mathrm{L}_{0}}\right) \times 100$

$\%$ Diameter shrinkage $=\left(\frac{\mathrm{D}_{0}-\mathrm{D}}{\mathrm{D}_{0}}\right) \times 100$

(Yamsaengsung et al., 2011)

Where $\mathbf{L}$ and $\mathbf{D}$ are the thickness and diameter of the dried sample, respectively. While $\mathbf{L}_{\mathbf{0}}$ and $\mathbf{D}_{\mathbf{0}}$ represent the initial values of the thickness and diameter of the sample prior to drying, respectively. The measurement of the area of the sample was performed using a digital digimatic Mitutoyo Model. 


\subsubsection{Texture analysis:}

The crispness and hardness of the final product were verified using a Texture Analyzer (Model c, EVERWELL CORPORATION, Tokyo Japan) fitted with a cutting probe. The test involved applying a direct force to the sample, which was placed on a hollow planar base. The cutting probe was set to move at a crosshead until it cracked the sample. The maximum compression force and the number of peaks of each sample were considered as an indication of hardness and crispness of the sample, respectively.

\subsubsection{Rehydration ability:}

The ability of dried banana slices to reconstitute to its original state when immersing them in UHT milk was described by the rehydration ratio (R). The rehydration ratio, measured in terms of the mass ratio, was evaluated by immersing dried banana sample in $600 \mathrm{ml}$ of UHT milk, preconditioned to $30^{\circ} \mathrm{C}$ by a water bath. After10 min the sample was taken out and blotted with paper towel to eliminate excess milk on its surface. The masses of the dried $(\mathrm{m})$ and rehydrated samples $\left(\mathrm{m}_{\mathrm{after}}\right)$ are measured by an electric balance with an accuracy of $\pm 0.01 \mathrm{~g}$. The rehydration ratio of the sample is then calculated by:

$$
\mathrm{R}=\frac{\mathrm{m}_{\mathrm{after}}}{\mathrm{m}}
$$

where:

$\mathrm{m}_{\mathrm{after}}=$ mass of sample after rehydration, $\mathrm{g}$;

$\mathrm{m}=$ mass of sample before rehydration, $\mathrm{g}$.

\subsubsection{Color changes:}

The color of samples was measured using an AGPtek USB 800X Digital Microscope Camera. The microscope is designed to have accurate banana sample pictures. Color changes were then compared the lightness, redness and yellowness by series of obtained pictures.

\section{RESULTS AND DISCUSSION}

\subsection{Influence of drying parameters on the change in banana slices moisture ratio:}

Figures 3 illustrates the change in banana slices moisture ratio as related to drying time at different levels of drying vacuum, surface temperature and slices thickness. As shown in the figures, the reduction in moisture 
ratio of banana slices was varied with the experimental treatments and it was increased with the increase of vacuum, and slices surface temperature. From Figures 3, it was found that, the drying temperature of $90{ }^{\circ} \mathrm{C}$ recorded the shortest time in comparison with other levels of tested temperature. In addition, the drying time also decreased with the increase in the drying vacuum. This is due to the fact that the product water evaporates at lower temperature when drying was performed at higher vacuum.

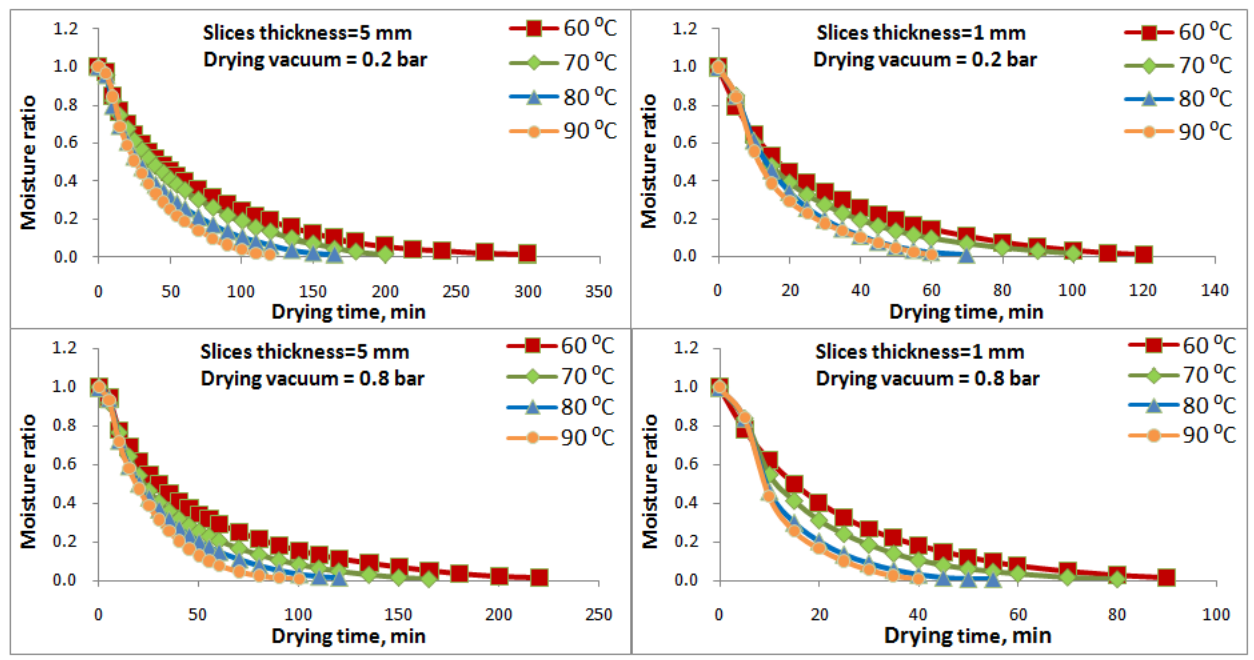

Figure (3): Banana slices moisture ratio as related to drying time at different levels of surface temperature and different vacuum at $1 \mathrm{~mm}$ and $5 \mathrm{~mm}$ slices thickness.

This result was similar to that of Nimmol et al. (2007). From the experimental data, the maximum drying time taken for the sample thickness of $5 \mathrm{~mm}$ to reach the final moisture content of about $3.7 \%$ d.b. was approximately 300 minutes at $60{ }^{\circ} \mathrm{C}$ and a vacuum of 0.2 bar. However, the minimum drying time taken for the sample thickness of $1 \mathrm{~mm}$ to reach the final moisture content of about $2.6 \%$ d.b. was approximately 40 minutes at $90{ }^{\circ} \mathrm{C}$ and a vacuum of 0.8 bar.

\subsection{Simulation of the drying behaviour of banana slices:}

The obtained data of the laboratory experiments was employed to examine and analyze the applicability of three different thin layer drying models (Lewis's, Henderson and Pabis's and the Logarithmic model) on describing and simulating the drying data. 


\subsubsection{Lewis's model:}

The values of drying constant $\left(k_{L}\right)$ for the Lewis's model could be obtained from the linear relationship between $\operatorname{Ln}(M R)$ of the tested sample versus the drying time $(t)$. The computed values of the drying constants $k_{L}$ are listed in Table 2 .

Table (2): Drying constant $\left(k_{L}\right)$ of Lewis's model.

\begin{tabular}{|c|c|c|c|c|c|}
\hline \multirow{2}{*}{$\begin{array}{c}\text { Slices } \\
\text { surface } \\
\text { temp. }{ }^{\circ} \mathrm{C}\end{array}$} & \multirow{2}{*}{$\begin{array}{c}\text { Slices } \\
\text { thickness, } \\
\text { mm }\end{array}$} & \multicolumn{4}{|c|}{ Vacuum, bar } \\
\hline & & 0.2 & 0.4 & 0.6 & 0.8 \\
\hline \multirow{2}{*}{60} & 1 & 0.0343 & 0.0383 & 0.0396 & $0: 0442$ \\
\hline & 5 & 0.0144 & 0.0161 & 0.0179 & 0.0194 \\
\hline \multirow{2}{*}{70} & 1 & 0.0400 & 0.0440 & 0.0486 & 0.0573 \\
\hline & 5 & 0.0188 & 0.0221 & 0.0244 & 0.0262 \\
\hline \multirow{2}{*}{80} & 1 & 0.0595 & 0.0671 & 0.0752 & 0.0900 \\
\hline & 5 & 0.0245 & 0.0269 & 0.0317 & 0.0350 \\
\hline \multirow{2}{*}{90} & 1 & 0.0632 & 0.0794 & 0.0843 & 0.1020 \\
\hline & 5 & 0.0332 & 0.0353 & 0.0412 & 0.0444 \\
\hline
\end{tabular}

As shown in Table 2, the drying constant $\left(K_{L}\right)$ increased with the increase of slices surface temperature and the increase of drying vacuum. However, it was decreased with the increase of slice thickness. A multiple regression analysis was employed to relate the studied parameters $\left(T, t_{h}\right.$ and $\left.V\right)$ with the drying constant $\left(k_{L}\right)$. The nature of dependence could be expressed by the following equation:

$$
\begin{array}{rl}
k_{L}=0.001131 & T-0.008367 t_{h} \\
& +0.026594 \mathrm{~V}-0.029326
\end{array}
$$

$$
\text { (S.E. } \left.=0.007274 \quad ; \quad \mathrm{R}^{2}=0.911235 ; \quad \mathrm{r}=0.954586\right)
$$

Where:

$T=$ Slices surface temperature,${ }^{\circ} \mathrm{C}$.

$t_{h}=$ Slices thickness, $\mathrm{mm}$.

$V=$ Drying vacuum, bar.

\subsubsection{Henderson and Pabis's model:}

A mathematical analysis of the experimental data and a calculation of the drying constants $\left(K_{H}\right)$ and $(A)$ were proceeded to simulate and describe the obtained drying curves and to assess the relationship between the drying constants and the studied drying parameters. The values of drying constants $\left(K_{H}\right)$ and $(A)$ for Henderson and Pabis's equation, as shown in 
Table 3, could be obtained from the linear relationship between $\operatorname{Ln}(M R)$ versus the drying time $(t)$ as follow:

$$
\operatorname{Ln} M R=\operatorname{Ln} A-K_{H} t
$$

The slope of the drying curve represents the drying constant $\left(K_{H}\right)$ while the constant $(A)$ could be calculated from the intercept. The computed values of the drying constants $\left(K_{H}\right)$ are listed in table 3 .

Table (3): Drying constant $\left(K_{H}\right)$ of Henderson and Pabis's model.

\begin{tabular}{|c|c|c|c|c|c|}
\hline \multirow{2}{*}{$\begin{array}{c}\text { Slices } \\
\text { surface } \\
\text { temp. }{ }^{\circ} \mathrm{C}\end{array}$} & \multirow{2}{*}{$\begin{array}{c}\text { Slices } \\
\text { thickness, mm }\end{array}$} & \multicolumn{4}{|c|}{ Vacuum, bar } \\
\hline & & 0.2 & 0.4 & 0.6 & 0.8 \\
\hline \multirow{2}{*}{60} & 1 & 0.0342 & 0.0382 & 0.0389 & 0.0448 \\
\hline & 5 & 0.0140 & 0.0160 & 0.0174 & 0.0190 \\
\hline \multirow{2}{*}{70} & 1 & 0.0391 & 0.0429 & 0.0482 & 0.0584 \\
\hline & 5 & 0.0196 & 0.0234 & 0.0252 & 0.0259 \\
\hline \multirow{2}{*}{80} & 1 & 0.0638 & 0.0703 & 0.0807 & 0.0968 \\
\hline & 5 & 0.0253 & 0.0272 & 0.0325 & 0.0366 \\
\hline \multirow{2}{*}{90} & 1 & 0.0672 & 0.0873 & 0.0903 & 0.1128 \\
\hline & 5 & 0.0371 & 0.0378 & 0.0456 & 0.0479 \\
\hline
\end{tabular}

As shown in Table 3, the drying constant $\left(K_{H}\right)$ increased with the increase of slices surface temperature and the increase of drying vacuum but it was decreased with the increase of slices thickness. The regression analysis showed no direct relationship between the constant (A) and the experimental variables. So, the drying constant (A) was taken as (1.1081) which represents the mean values of the calculated value. A multiple regression analysis was conducted to relate the studied parameters $(T$, $t_{h}$ and $V$ ) with the drying constant $\left(k_{H}\right)$. The nature of dependence could be expressed by the following equation:

$k_{H}=0.001326 T-0.008803 t_{h}+0.028837 V-0.041715 \ldots$ (10) (S.E. $\left.=0.008803 \quad ; \quad R^{2}=0.893904 ; \quad r=0.945465\right)$

\subsubsection{The logarithmic model:}

A mathematical analysis of the experimental data and a calculation of the drying constants $\left(K_{L O G}\right),(B)$ and $(C)$ were proceeded to simulate and describe the obtained drying curves and to assess the relationship between the drying constants and the studied drying parameters. The values of drying constants $\left(K_{L O G}\right),(B)$ and $(C)$ for the Logarithmic 
equation, as shown in Table 4, could be obtained using a developed computer program based on MATLAB.

$$
M R=B \cdot \exp \left(-K_{L O G} t\right)+C
$$

The computed values of the drying constants $\left(\mathrm{K}_{\mathrm{LOG}}\right)$ for the Logarithmic model which computed by the MATLAB program are listed in Table 4.

Table (4): Drying constant $\left(\boldsymbol{K}_{\boldsymbol{L O G}}\right)$ of the Logarithmic model.

\begin{tabular}{|c|c|c|c|c|c|}
\hline \multirow{2}{*}{$\begin{array}{c}\text { Slices } \\
\text { surface } \\
\text { temp. }{ }^{\circ} \mathrm{C}\end{array}$} & \multirow{2}{*}{$\begin{array}{c}\text { Slices } \\
\text { thickness, } \\
\text { mm }\end{array}$} & \multicolumn{4}{|c|}{ Vacuum, bar } \\
\hline & & 0.2 & 0.4 & 0.6 & 0.8 \\
\hline \multirow{2}{*}{60} & 1 & 0.0362 & 0.0400 & 0.0433 & 0.0444 \\
\hline & 5 & 0.0159 & 0.0168 & 0.0208 & 0.0228 \\
\hline \multirow{2}{*}{70} & 1 & 0.0464 & 0.0518 & 0.0536 & 0.0579 \\
\hline & 5 & 0.0179 & 0.0199 & 0.0242 & 0.0299 \\
\hline \multirow{2}{*}{80} & 1 & 0.0507 & 0.0597 & 0.0643 & 0.0729 \\
\hline & 5 & 0.0245 & 0.0292 & 0.0330 & 0.0340 \\
\hline \multirow{2}{*}{90} & 1 & 0.0585 & 0.0613 & 0.0687 & 0.0729 \\
\hline & 5 & 0.0268 & 0.0324 & 0.0345 & 0.0379 \\
\hline
\end{tabular}

As shown in Table 4 the drying constant $\left(K_{L O G}\right)$ increased with the increase of slices surface temperature and the increase of drying vacuum but it was decreased with the increase of slices thickness. It was found that, the drying constant $\left(K_{L O G}\right)$ depending on the slices surface temperature $(T)$, drying vacuum $(V)$ and slices thickness $\left(t_{h}\right)$. The regression analysis showed no direct relationship between the constants $(B, C)$ and the experimental variables. So, the drying constant $(B, C)$ was taken as (1.021-0.0024) which represented the mean values of the calculated value. A multiple regression analysis was also proceeded to relate the studied parameters $\left(T, t_{h}\right.$ and $\left.V\right)$ with the drying constant $\left(k_{L O G}\right)$. The nature of dependence could be expressed by the following equation:

$$
\begin{aligned}
& k_{L O G}=0.000656 T-0.007220 t_{h}+0.019919 \mathrm{~V}+0.003195 \ldots(12) \\
&\left(\text { S.E. }=0.003252 \quad ; \quad \mathrm{R}^{2}=0.96822 ; \quad \mathrm{r}=0.983998\right)
\end{aligned}
$$

\subsubsection{Comparative evaluation of the studied drying models:}

A comparison study for the three drying models (Lewis's; Henderson and Pabis's; Logarithmic model) was conducted to assess the most proper drying model for simulating and describing the drying behavior of 
banana slices under the studied range of experimental parameters. Table 5 presents the overall average of the obtained coefficient of determination $\left(\mathrm{R}^{2}\right)$ and the standard error (SE) for the observed and the calculated moisture ratio.

Table (5): The overall average of the obtained $\left(\mathrm{R}^{2}\right)$ and (SE) for all studied drying models

\section{The model Coefficient of $\quad$ Standard error (SE) determination $\left(\mathbf{R}^{2}\right)$}

\begin{tabular}{lcc}
\hline Lewis & 0.9915 & 0.0266 \\
$\begin{array}{l}\text { Henderson and } \\
\text { Pabis's }\end{array}$ & 0.9892 & 0.0342 \\
logarithmic & 0.9938 & 0.0239 \\
\hline
\end{tabular}

The results showed that, all the studied models could describe the drying behavior of banana slices as indicated from the higher values of coefficient of determination $\left(\mathrm{R}^{2}\right)$ for all models which ranged from (0.9892 to 0.9938). On the other hand Lewis's model and the Logarithmic model showed very close values of coefficient of determination $\left(\mathrm{R}^{2}\right)$ and standard error (SE). So it may said that, both models could be satisfactorily described the drying behavior of banana slices. Also general comparison was conducted between the two selected models based on the statistical analysis between the observed and the calculated values of moisture ratio to assess the most proper model for describing the drying behavior of banana slices. In addition to high value of correlation coefficient ( $r$ ), various statistical parameters such as; reduced chi-square $\left(\mathrm{x}^{2}\right)$, mean bias error $(\mathrm{MBE})$ and root mean square error (RMSE) were computed. The computed values of chi-square $\left(x^{2}\right)$, mean bias error (MBE), root mean square error (RMSE) and correlation coefficient (r) are listed in Table 6.

As shown in Table 6, the Logarithmic model showed the highest values of coefficient of correlation (r), lowest values of chi-square $\left(x^{2}\right)$ and root mean square error (RMSE). So the Logarithmic model was the most proper model in describing the drying behavior of banana slices.

\subsection{Quality of Banana Slices:}

\subsubsection{Shrinkage of banana slices:}

Figure 6 compares shrinkage of dried samples at various temperatures; it 
was found that the shrinkage rate increased with the decrease in slices surface temperature and drying vacuum. In addition, it was found that the slices thickness shrinkage of bananas was higher than diameter shrinkage. Table (6): Values of coefficient of determination (r), chi-square $\left(x^{2}\right)$, mean bias error $(M B E)$ and root mean square error (RMSE) Lewis's model and the Logarithmic model.

\begin{tabular}{|c|c|c|c|c|c|c|c|c|c|c|}
\hline \multirow{2}{*}{$\begin{array}{l}\text { Slices } \\
\text { surface } \\
\text { temp. } \\
\left({ }^{\circ} \mathrm{C}\right)\end{array}$} & \multirow{2}{*}{$\begin{array}{l}\text { Vacuum, } \\
\text { bar }\end{array}$} & \multirow{2}{*}{$\begin{array}{c}\text { Slices } \\
\text { thickness, } \\
\text { mm }\end{array}$} & \multicolumn{4}{|c|}{ Lewis's model } & \multicolumn{4}{|c|}{ Logarithmic model } \\
\hline & & & $\mathbf{r}$ & $x^{2}$ & MBE & RMSE & $\mathbf{r}$ & $x^{2}$ & MBE & RMSE \\
\hline \multirow{8}{*}{60} & \multirow{2}{*}{0.2} & 1 & 0.99735 & 0.00089 & 0.00925 & 0.02895 & 0.99654 & 0.00140 & -0.01280 & 0.03413 \\
\hline & & 5 & 0.99725 & 0.00091 & 0.01519 & 0.02962 & 0.99750 & 0.00079 & -0.00387 & 0.02760 \\
\hline & \multirow{2}{*}{0.4} & 1 & 0.99900 & 0.00035 & 0.00627 & 0.01820 & 0.99875 & 0.00054 & -0.00036 & 0.02108 \\
\hline & & 5 & 0.99765 & 0.00069 & 0.00921 & 0.02574 & 0.99755 & 0.00089 & 0.00438 & 0.02808 \\
\hline & \multirow{2}{*}{0.6} & 1 & 0.99880 & 0.00047 & 0.01101 & 0.02094 & 0.99880 & 0.00057 & -0.00692 & 0.02159 \\
\hline & & 5 & 0.99659 & 0.00118 & 0.01920 & 0.03361 & 0.99755 & 0.00093 & -0.01189 & 0.02866 \\
\hline & \multirow{2}{*}{0.8} & 1 & 0.99965 & 0.00011 & -0.00004 & 0.01011 & 0.99940 & 0.00029 & 0.00304 & 0.01514 \\
\hline & & 5 & 0.99579 & 0.00133 & 0.01857 & 0.03575 & 0.99685 & 0.00122 & -0.01579 & 0.03265 \\
\hline \multirow{8}{*}{70} & \multirow{2}{*}{0.2} & 1 & 0.99589 & 0.00100 & 0.01323 & 0.03064 & 0.99695 & 0.00106 & -0.01783 & 0.02959 \\
\hline & & 5 & 0.99815 & 0.00053 & -0.01280 & 0.02253 & 0.99825 & 0.00050 & 0.00587 & 0.02090 \\
\hline & \multirow{2}{*}{0.4} & 1 & 0.99534 & 0.00104 & 0.01184 & 0.03128 & 0.99685 & 0.00962 & -0.02211 & 0.08843 \\
\hline & & 5 & 0.99765 & 0.00099 & -0.02344 & 0.03079 & 0.99920 & 0.00047 & 0.00883 & 0.02024 \\
\hline & \multirow{2}{*}{0.6} & 1 & 0.99700 & 0.00063 & 0.00392 & 0.02419 & 0.99740 & 0.00082 & -0.01537 & 0.02563 \\
\hline & & 5 & 0.99955 & 0.00019 & -0.01019 & 0.01360 & 0.99945 & 0.00013 & -0.00321 & 0.01072 \\
\hline & \multirow{2}{*}{0.8} & 1 & 0.99740 & 0.00068 & -0.00707 & 0.02511 & 0.99725 & 0.00070 & -0.00602 & 0.02353 \\
\hline & & 5 & 0.99685 & 0.00069 & 0.00822 & 0.02566 & 0.99760 & 0.00093 & -0.01935 & 0.02817 \\
\hline \multirow{8}{*}{80} & \multirow{2}{*}{0.2} & 1 & 0.99654 & 0.00190 & -0.02837 & 0.04183 & 0.99830 & 0.00094 & 0.01497 & 0.02685 \\
\hline & & 5 & 0.99825 & 0.00047 & -0.01125 & 0.02124 & 0.99810 & 0.00047 & -0.00645 & 0.01974 \\
\hline & \multirow{2}{*}{0.4} & 1 & 0.99549 & 0.00187 & -0.02235 & 0.04139 & 0.99679 & 0.00127 & 0.00916 & 0.03091 \\
\hline & & 5 & 0.99715 & 0.00058 & -0.00273 & 0.02341 & 0.99730 & 0.00090 & -0.01803 & 0.02770 \\
\hline & \multirow{2}{*}{0.6} & 1 & 0.99252 & 0.00338 & -0.03097 & 0.05541 & 0.99428 & 0.00235 & 0.01014 & 0.04132 \\
\hline & & 5 & 0.99745 & 0.00060 & -0.00871 & 0.02377 & 0.99745 & 0.00075 & -0.01423 & 0.02519 \\
\hline & \multirow{2}{*}{0.8} & 1 & 0.98869 & 0.00494 & -0.03593 & 0.06703 & 0.99242 & 0.00315 & 0.01162 & 0.04783 \\
\hline & & 5 & 0.99755 & 0.00091 & -0.01802 & 0.02932 & 0.99750 & 0.00061 & -0.00649 & 0.02261 \\
\hline \multirow{8}{*}{90} & \multirow{2}{*}{0.2} & 1 & 0.99579 & 0.00166 & -0.02221 & 0.03905 & 0.99614 & 0.00117 & 0.00051 & 0.02968 \\
\hline & & 5 & 0.99489 & 0.00430 & -0.05176 & 0.06371 & 0.99785 & 0.00112 & 0.00984 & 0.03059 \\
\hline & \multirow{2}{*}{0.4} & 1 & 0.99056 & 0.00492 & -0.04290 & 0.06691 & 0.99539 & 0.00271 & 0.02217 & 0.04439 \\
\hline & & 5 & 0.99715 & 0.00202 & -0.03053 & 0.04363 & 0.99765 & 0.00092 & -0.00329 & 0.02750 \\
\hline & \multirow{2}{*}{0.6} & 1 & 0.98914 & 0.00513 & -0.03528 & 0.06795 & 0.99217 & 0.00404 & 0.01747 & 0.05320 \\
\hline & & 5 & 0.99564 & 0.00320 & -0.04329 & 0.05490 & 0.99810 & 0.00076 & 0.00517 & 0.02506 \\
\hline & \multirow{2}{*}{0.8} & 1 & 0.98148 & 0.00971 & -0.05249 & 0.09217 & 0.98823 & 0.00887 & 0.03712 & 0.07446 \\
\hline & & 5 & 0.99584 & 0.00274 & -0.03600 & 0.05067 & 0.99775 & 0.00102 & 0.00800 & 0.02882 \\
\hline \multicolumn{3}{|c|}{ Average } & 0.99575 & 0.00188 & -0.01251 & 0.03716 & 0.99693 & 0.00162 & -0.00049 & 0.03163 \\
\hline
\end{tabular}


This result was similar to that of Nimmol et al. (2007). Moreover, it was found that thickness and diameter shrinkage of dried bananas at $90{ }^{\circ} \mathrm{C}$ were lower than those dried at 60,70 and $80{ }^{\circ} \mathrm{C}$. Panyawong and Devahastin (2007) and Swasdisevi et al. (2007) reported that the shrinkage was the least at the highest temperature of drying, similar tendency was also observed at the present study.

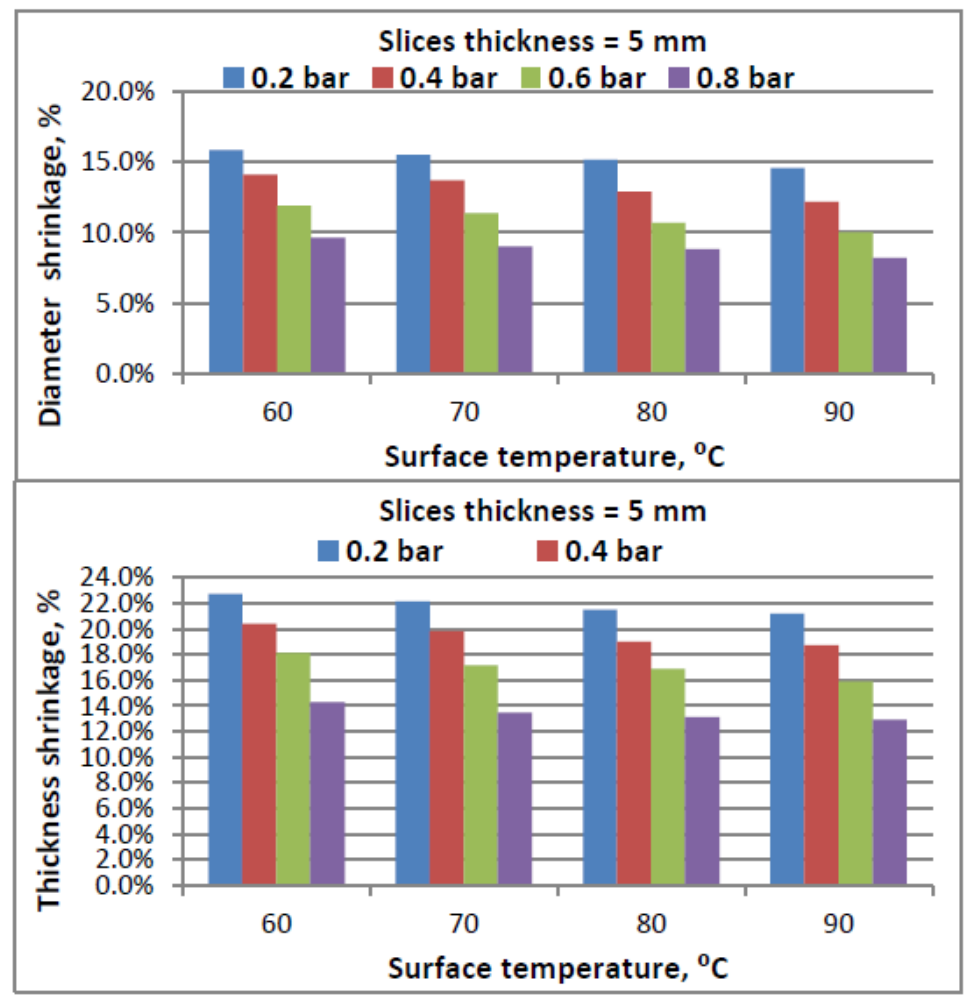

Figure (6): Effects of surface temperature and drying vacuum levels on shrinkage of dried banana slices at $5 \mathrm{~mm}$ slices thickness.

3.3.2. Textural change (hardness and crispness of the dried banana slices):

Table 7 shows the hardness (Maximum force) and crispness (Number of peaks) of banana slices at different drying condition. It was found that the hardness of dried banana at $60{ }^{\circ} \mathrm{C}$ was significantly higher than those dried at 70, 80 and $90{ }^{\circ} \mathrm{C}$. This result was similar to Thomkapanich (2006) who also found that for vacuum drying of banana, the hardness increased with decreasing temperatures. Mean while, it was found that banana slices dried at $5 \mathrm{~mm}$ thickness were harder than those dried at 1 $\mathrm{mm}$ thickness, as indicated by the higher value of the maximum force. 
Table (7): Effects of surface temperature, drying vacuum and thickness on hardness (maximum force) and crispness (number of peaks) of dried bananas.

\begin{tabular}{|c|c|c|c|c|}
\hline $\begin{array}{l}\text { Slices surface } \\
\text { temp. }{ }^{\circ} \mathrm{C}\end{array}$ & $\begin{array}{c}\text { Drying } \\
\text { vacuum, bar }\end{array}$ & $\begin{array}{c}\text { Slices thickness, } \\
\text { mm }\end{array}$ & $\begin{array}{l}\text { Maximum } \\
\text { Force (N) } \\
\end{array}$ & $\begin{array}{c}\begin{array}{c}\text { Number of } \\
\text { peaks }\end{array} \\
\end{array}$ \\
\hline \multirow{8}{*}{60} & \multirow{2}{*}{0.2} & 1 & 8.93 & 32 \\
\hline & & 5 & 26.61 & 17 \\
\hline & \multirow{2}{*}{0.4} & 1 & 8.60 & 34 \\
\hline & & 5 & 23.49 & 18 \\
\hline & \multirow{2}{*}{0.6} & 1 & 6.42 & 37 \\
\hline & & 5 & 22.25 & 19 \\
\hline & \multirow{2}{*}{0.8} & 1 & 6.26 & 36 \\
\hline & & 5 & 19.62 & 20 \\
\hline \multirow{8}{*}{70} & \multirow{2}{*}{0.2} & 1 & 8.41 & 31 \\
\hline & & 5 & 24.41 & 17 \\
\hline & \multirow{2}{*}{0.4} & 1 & 7.50 & 34 \\
\hline & & 5 & 20.12 & 22 \\
\hline & \multirow{2}{*}{0.6} & 1 & 6.34 & 35 \\
\hline & & 5 & 18.44 & 21 \\
\hline & \multirow{2}{*}{0.8} & 1 & 6.27 & 34 \\
\hline & & 5 & 16.50 & 23 \\
\hline \multirow{8}{*}{80} & \multirow{2}{*}{0.2} & 1 & 8.63 & 35 \\
\hline & & 5 & 20.78 & 18 \\
\hline & \multirow{2}{*}{0.4} & 1 & 7.73 & 33 \\
\hline & & 5 & 19.92 & 21 \\
\hline & \multirow{2}{*}{0.6} & 1 & 6.24 & 32 \\
\hline & & 5 & 17.16 & 23 \\
\hline & \multirow{2}{*}{0.8} & 1 & 6.22 & 38 \\
\hline & & 5 & 14.76 & 26 \\
\hline \multirow{8}{*}{90} & \multirow{2}{*}{0.2} & 1 & 8.60 & 33 \\
\hline & & 5 & 21.80 & 18 \\
\hline & \multirow{2}{*}{0.4} & 1 & 7.70 & 31 \\
\hline & & 5 & 18.86 & 22 \\
\hline & \multirow{2}{*}{0.6} & 1 & 6.44 & 35 \\
\hline & & 5 & 18.04 & 21 \\
\hline & \multirow{2}{*}{0.8} & 1 & 6.28 & 34 \\
\hline & & 5 & 15.85 & 27 \\
\hline
\end{tabular}

However, the effect of slices surface temperature and drying vacuum at $1 \mathrm{~mm}$ thickness of banana slices on the hardness showed that, at the same drying temperature, the hardness of dried banana slices was lower than that of samples dried by higher vacuum. In addition, this table shows that the crispness of dried bananas at $80{ }^{\circ} \mathrm{C}$ and $90{ }^{\circ} \mathrm{C}$ was higher than those dried at 60 and $70{ }^{\circ} \mathrm{C}$ while it was in very close values with $90{ }^{\circ} \mathrm{C}$. These 
results were similar to Thomkapanich (2006). In terms of crispness it can be seen again from Table 7 that at $1 \mathrm{~mm}$ thickness the dried banana slices showed a larger number of peaks (hence indicating that the products were crispier) compared at $5 \mathrm{~mm}$ thickness, especially at $80{ }^{\circ} \mathrm{C}$. However, the effect of studied drying process on the number of peaks was not clear when drying temperature increased to $90{ }^{\circ} \mathrm{C}$ since the crispness values were very close at both levels.

\subsubsection{Rehydration rate of banana slices:}

In terms of rehydration behavior of the dried banana slices it can be seen from Table 8, that the dried banana samples at high temperature showed higher rehydration ability compared with those dried at low temperature. Nimmol et al. (2007) reported that higher temperature drying leads to higher porous structure of the dried product, thus facilitating rehydration ability.

Table (8): Effects of drying temperature, vacuum and thickness on rehydration ratio of dried bananas.

\begin{tabular}{|c|c|c|c|c|c|}
\hline \multirow{2}{*}{$\begin{array}{l}\text { Slices surface } \\
\text { temp. }{ }^{\circ} \mathrm{C}\end{array}$} & \multirow{2}{*}{$\begin{array}{c}\text { Slices } \\
\text { thickness, mm }\end{array}$} & \multicolumn{4}{|c|}{ Vacuum, bar } \\
\hline & & 0.2 & 0.4 & 0.6 & 0.8 \\
\hline \multirow{2}{*}{60} & 1 & 1.83 & 1.88 & 1.90 & 2.05 \\
\hline & 5 & 1.52 & 1.55 & 1.59 & 1.72 \\
\hline \multirow{2}{*}{70} & 1 & 1.85 & 1.90 & 1.95 & 2.10 \\
\hline & 5 & 1.54 & 1.56 & 1.60 & 1.74 \\
\hline \multirow{2}{*}{80} & 1 & 1.87 & 1.93 & 1.98 & 2.14 \\
\hline & 5 & 1.55 & 1.56 & 1.62 & 1.76 \\
\hline \multirow{2}{*}{90} & 1 & 1.85 & 1.95 & 1.98 & 2.17 \\
\hline & 5 & 1.58 & 1.57 & 1.63 & 1.78 \\
\hline
\end{tabular}

In general, the highest drying vacuum ( 0.8 bar $)$ showed the highest rehydration ability. In addition, the dried samples at $5 \mathrm{~mm}$ thickness showed lower rehydration ability compared with those dried at $1 \mathrm{~mm}$ thickness. This is due to the thick sample and low temperature drying for a long period of time causes a dense structure in the products due to its shrinkage.

\subsubsection{Color changes of banana slices:}

As shows in Figure 7, it was found that the lightness of dried bananas at $90{ }^{\circ} \mathrm{C}$ were significantly lower than those dried at 60,70 and $80{ }^{\circ} \mathrm{C}$. The redness and yellowness at $90{ }^{\circ} \mathrm{C}$ were significantly higher than those dried at 60,70 and $80{ }^{\circ} \mathrm{C}$. This is due to browning reaction occurring during drying process at this level of temperature. The change in color of dried banana samples in this drying temperature range showed a little 
effect. However due to shorter drying time at drying temperature of 80 ${ }^{\circ} \mathrm{C}$, the effect on banana slices color was the least.

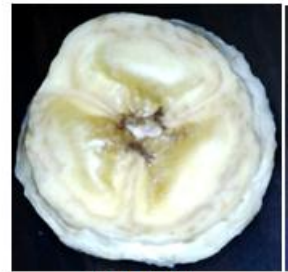

$\left(60^{\circ} \mathrm{C}\right)$

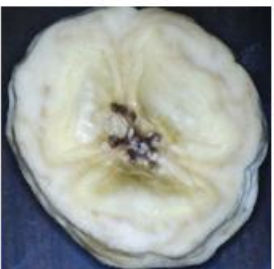

$\left(70^{\circ} \mathrm{C}\right)$

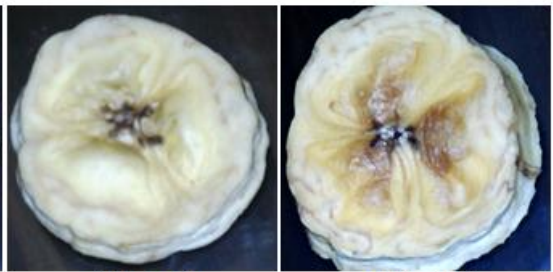

$\left(90{ }^{\circ} \mathrm{C}\right)$

Figure (7): Photographs showing banana slices with different surface temperature at 0.8 bar drying vacuum.

Figure 8 shows that the redness of dried banana slices was also affected by the drying vacuum. Lower vacuum yielded redder dried banana than drying at higher vacuums. In the case of yellowness, it was found that banana slices dried at higher vacuum tended to have lower yellowness than those dried at lower vacuum.

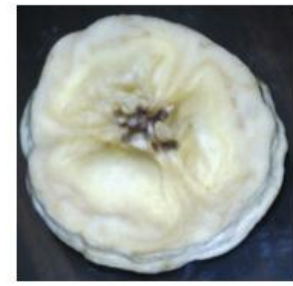

(0.8 bar)

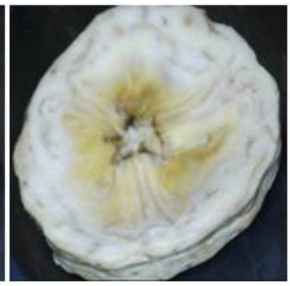

(0.6 bar)

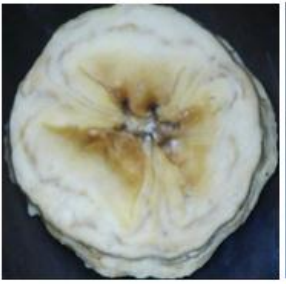

(0.4 bar)

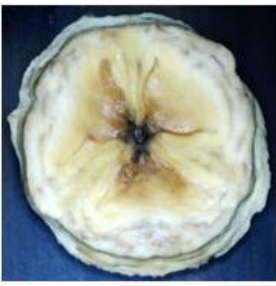

(0.2 bar)

Figure (8): Photographs showing banana slices dried at different drying vacuum and $80^{\circ} \mathrm{C}$ surface temperature.

Figure 9 shows the color changes of the dried banana with different slice thicknesses at a surface temperature of $80{ }^{\circ} \mathrm{C}$ under drying vacuum of 0.8 bar. It was found that, there are no substantial differences in lightness, redness and yellowness between the dried samples at thickness of $1 \mathrm{~mm}$ and $5 \mathrm{~mm}$.

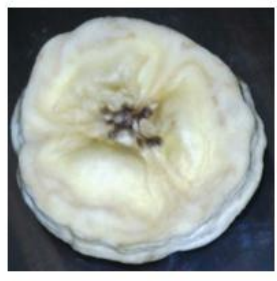

(5 mm)

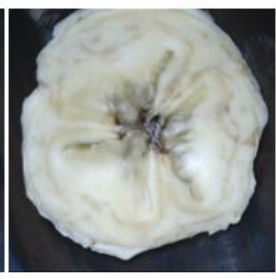

(1 mm)

Figure (9): Photographs showing banana slices with different thickness at $80{ }^{\circ} \mathrm{C}$ surface temperature and 0.8 bar drying vacuum. 


\section{CONCLUSION}

1- The combined vacuum and infrared (IR) drying system are recommended for drying the heat sensitive materials to decrease drying time and obtain high quality dried product.

2- The changes of surface banana temperature showed significant effect on decreasing drying time than changes of drying vacuum and slices thickness.

3- The Logarithmic model is recommended for describing the drying behavior and predicted the change of moisture ratio of banana slices.

4- The vacuum -infrared drying method at drying vacuum of 0.8 bar, drying surface temperature of $80{ }^{\circ} \mathrm{C}$ and slices thickness of $1 \mathrm{~mm}$ is recommended for (good color, low shrinkage, high rehydration behavior and acceptable texture change).

\section{REFERENCES}

Boudhrioua, N., N. Bahloul, B.I. Slimen and N. Kechaou (2009). Comparison on the total phenol contents and the color of fresh and infrared dried olive leaves. Industrial Crops and Products, 29: 412419.

Henderson, S.M. and S. Pabis (1961). Grain drying theory II: temperature effect on drying coefficients. J Agric Eng Res, 6: 11111122 .

Jaya, S. and H. Das (2003). A vacuum drying model for mango pulp. Dry Technology, 21: 1215-1234.

Junlakan, W. (2014). Effect of Drying Kinetics on the Quality of Vacuum-Dried Banana, Pineapple and. Apple Slices. Ph.D. Thesis, Chemical Engineering, Songkla University, Thailand.

Lewis, W.K. (1921). The rate of drying of solid materials. Ind Eng Chem, 13:427-443.

Limpaiboon, K. (2011). Effects of temperature and slice thickness on drying kinetics of pumpkin slices. Walailak Journal of Science and Technology, 8(2): 159-166.

MoA (2014). Horticulture Research Institute Pamphlet. Agric. Res. Center. Ministry of Agric. 
Nimmol, C., S. Devahastin, T. Swasdisevi, S. Soponronnarit (2007). Drying of banana slices using combined low-pressure superheated steam and far-infrared radiation. Journal of Food Engineering, 8(3): 624-633.

Pangavhane, D.R.; R.L. Sawhnew and P.N. Sarsavadia (2000). Drying kinetic studies on single later Thompson seedless grape controlled heated air conditions. Journal of Food Engineering and Preservation, 24: 335-352.

Panyawong, S. and S. Devahastin (2007). Determination of deformation of a food product undergoing different drying methods and conditions via evolution of a shape factor. Journal of Food Engineering, 78(1): 151-161.

Sarsavadia, P.N.; R.L. Sawhney; D.R. Pangavhane; and S.P. Singh (1999). Drying behavior of brined onion slices. Journal of Food Engineering, 40: 219-226.

Swasdisevi, T., S. Devahastin, R. Ngamchum and S. Soponronnarit (2007). Optimization of a drying process using infrared vacuum drying of Cavendish banana slices. Songklanakarin Journal of Science and Technology, 29(3): 809-816.

Thomkapanich, O. (2006). Study of intermittent low-pressure superheated steam and vacuum drying of banana. Master thesis, Department of Food Engineering, King University of Technology Thonburi.

Thuwapanichayanan, R., S. Prachayawarakorn and S. Soponronnarit (2012). Effects of foaming agents and foam density on drying characteristics and textural property of banana foams. Journal of Food Science and Technology, 47(2): 348-357.

Timoumi, S., D. Mihoubi and F. Zagrouba (2007). Shrinkage, vitamin $\mathrm{C}$ degradation and aroma losses during infrared drying of apple slices. LWT-Food Science and Technology 40, 1648-1654.

Wanyo, P., S. Siriamornpun and N. Meeso (2011). Improvement of quality and antioxidant properties of dried mulberry leaves with combined far-infrared radiation and air convection in Thai tea 
process. Food and Bioproducts Processing, 89: 22-30.

Yagcioglu, A., A. Degirmencioglu and F. Cagatay (1999). Drying characteristic of laurel leaves under different conditions. In: Bascetincelik A (ed) Proceeding of the 7th international congress on agricultural mechanization and energy, Adana.

Yamsaengsung, R., T. Ariyapuchai and K. Prasertist (2011). Effects of vacuum frying on structural changes of bananas. Journal of Food Engineering, 106(4): 298-305.

Zakipour, E. and Z. Hamidi (2011). Vacuum drying characteristics of some vegetables. Iranian Journal of Chemistry and Chemical Engineering, 30(4): 97-105.

\section{الملخص العربيى}

\section{تجفيف شرائح الموز بنظام التفريغ ـ التسخين بالاشعة تحت الحمراء}

ريهام محمد كامل '، محمد مصطفي الخولي ‘ و اسماعيل احمد عبد المطلبّ

تم أختبار نظام التجفيف المدمج بالتفريغ ـ الأشعة تحت الحمر اء للمو اد الحساسة للحر ارة. أجريت

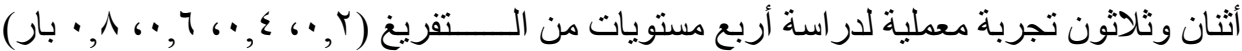

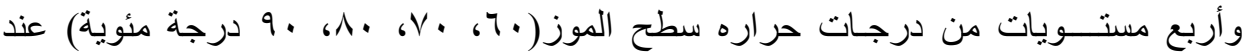

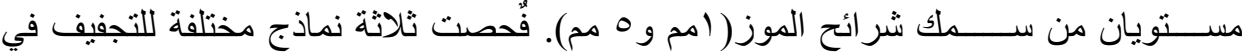
طبقة رقيقة (معادلة Lewis, معادلة Pabis Henderson and, معادلة Logarithmic) لتقييم نموذج التجفيف الأكثر ملائمة لمحاكاة ووصف سلوك التجفيف لشر ائح الموز تحت الدراسة لمتغيرات التجربة. تم تقييم الصفات الفيزيائية لشرائح الموز المجفف من حيث (اللون، أعاده

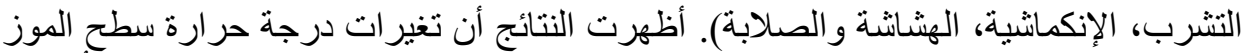

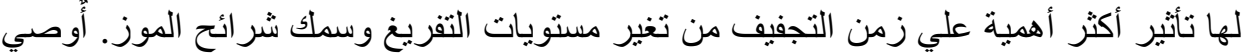
باستخدام النموذج المعادلة Logarithmic لوصف عملية التجفيف و التنبؤ بنسبة الرطوبة لثئ لثر ائح

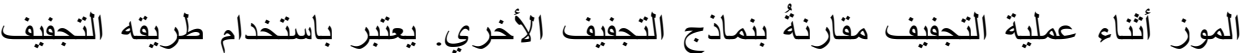

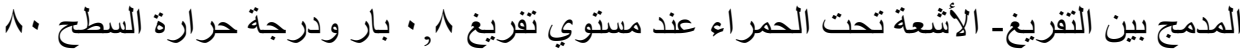
درجة مئوية وسمك شر ائح الموز 1 مم الأكثر ملائمة لتجفيف شر ائح الموز

'باحث مساعد - معهد بحوث الهندسه الزراعية_ الدقي - الجيزه.

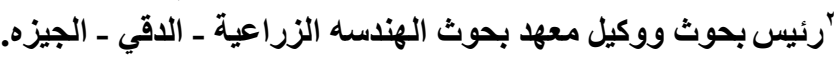
" أستاذ الهندسة الزراعية ـ كلية الزراعة ـ جامعة كفر الثيخ. 